\title{
KUALITAS LINGKUNGAN PERMUKIMAN KAWASAN INDUSTRI DI KECAMATAN GENUK KOTA SEMARANG
}

\author{
Settlement Environmental Quality of Industrial Area, Genuk District \\ Semarang City
}

\section{Septi Ayuningtyas ${ }^{1}$, Bitta Pigawati $^{1}$}

Diterima: 31 Agustus $2018 \quad$ Disetujui: 17 Oktober 2018

\begin{abstract}
Abstrak: Peningkatan jumlah dan aktivitas penduduk berimplikasi pada pertambahan luas area terbangun, terutama untuk fungsi permukiman. Terdapat berbagai karakter lingkungan permukiman di kawasan industri pinggiran Kota Semarang. Salah satu kawasan industri terbesar di Kota Semarang berlokasi di Kecamatan Genuk. Terdapat permukiman di Kecamatan Genuk yang berada di kawasan industri dan terkena bencana rob. Kawasan ini dikhawatirkan mengalami penurunan kualitas lingkungan permukiman. Penduduk masih banyak bermukim di bagian utara wilayah Kecamatan Genuk yang terkena banjir rob dan mengalami penurunan muka tanah. Kondisi tersebut dapat berimplikasi pada penurunan kualitas lingkungan permukiman di Kecamatan Genuk. Penelitian kualitas lingkungan permukiman di Kecamatan Genuk bertujuan untuk menganalisis perubahan kualitas lingkungan permukiman, menggunakan pendekatan spasial metode penginderaan jauh dan Geographic Information System (GIS). Teknik analisis weighted overlay menggunakan variabel kepadatan permukiman, tata letak bangunan, kondisi jalan masuk, lebar jalan masuk, pohon pelindung, lokasi permukiman dan kualitas atap bangunan yang mengacu pada penilaian Departemen Pekerjaan Umum. Hasil penelitian menunjukkan bahwa selama 10 tahun telah terjadi penurunan kualitas lingkungan permukiman di Kecamatan Genuk, yaitu di Kelurahan Sembungharjo dan Kelurahan Genuksari. Hal ini terjadi akibat peningkatan kepadatan permukiman dan berkurangnya pohon pelindung.
\end{abstract}

Keyword: GIS, environment quality, settlement, Genuk

\begin{abstract}
The increase in the number and activity of the population implies increasing the area woke up, especially for the neighborhood. There are a variety of different settlement environment character in the suburban area of Semarang. The existence of settlements in district Genuk which is in the industry and affected rob feared decline of environmental quality neighborhoods. There are still many residents living in the northern part of Kecamatan Genuk flooded rob and decline the face of the land. The condition can have implications for environmental degradation in neighborhoods in district Genuk. Research on environmental quality neighborhoods in district Genuk aims to analyze the changes in environmental quality neighborhoods, using a spatial approach to the method of remote sensing and Geographic Information System (GIS). Analytical techniques weighted overlay using the variable density of settlements, the layout of the buildings, the condition of the wide driveway, driveway, tree protectors, the location of settlements and the quality of the roof of the building refers to the assessment of the Department of public works. Results show that for 10 years of environmental degradation has occurred in district neighborhoods Genuk, namely in Sembungharjo Village and Genuksari Village. This occurs due to the increased density of settlements and the decline of the tree protectors.
\end{abstract}

Keyword: GIS, environment quality, settlement, Genuk

\footnotetext{
${ }^{1}$ Departemen Perencanaan Wilayah dan Kota, Fakultas Teknik Universitas Diponegoro
} 


\section{PENDAHULUAN}

Urbanisasi pada kota-kota metropolitan telah membawa dampak pada beberapa aspek, terutama aspek ruang dan lingkungan. Pertumbuhan penduduk yang berkembang dengan cepat berimplikasi pada makin besarnya kebutuhan ruang untuk tempat tinggal dan fasilitas lainnya (Sutanto, 1995). Permukiman adalah bentuk nyata wujud pemenuhan kebutuhan manusia terhadap ruang. Urbanisasi telah menjadi kekuatan yang mengubah lingkungan. Pertumbuhan penduduk berimplikasi pada meningkatnya kebutuhan ruang untuk tempat tinggal dan beraktifitas. Sesuai dengan yang dikemukaan oleh WhyneHammond (Whyne-Hammond, 1985), bahwa permukiman secara esensial merupakan struktur dinamis, mereka berubah seiring dengan waktu dan dalam responnya mengubah karakteristik dari lingkungannya. Tren demografis yang terus-menerus yang terkonsentrasi di kota berkontribusi paling besar sebagai salah satu penyebab kerusakan lingkungan, tergantung pada mobilitas urbanisasi di setiap kota (Aguilar, 2008).

Permukiman merupakan sebuah system yang terdiri dari lima unsur, yaitu: alam, masyarakat, manusia, lindungan dan jaringan. Bagian permukiman yang disebut wadah tersebut merupakan paduan tiga unsur: alam (tanah, air, udara), shell dan networks, sedang isinya adalah manusia dan masyarakat (Doxiadis, 1968). Permukiman yang terletak di pinggiran kota dengan masalah bencana dan berada di kawasan industri merupakan fenomena yang menarik dibahas kualitas lingkungan permukimannya. Lingkungan atau area-area yang mendukung tumbuhnya sector informal seringkali memiliki kualitas lingkungan yang kurang baik (MacDonald, J., Ziss, n.d.)

Rencana Detail Tata Ruang Kota Semarang (BWK IV Kecamatan Genuk) mengarahkan Kecamatan Genuk sebagai salah satu lokasi pengembangan industri. Hal tersebut dapat berpengaruh pada tata letak permukiman yang sudah ada. Perencanaan jangka panjang dari investasi public dapat mempengaruhi struktur permukiman (Rojas, 1989). Terjadi konversi lahan non terbangun menjadi lahan permukiman dan industri Kecamatan Genuk. Perkembangan kawasan industri ini berdampak pada bertambah luasnya kawasan permukiman. Konversi lahan untuk permukiman dan industri di kecamatan Genuk dalam kurun waktu 5 tahun dari tahun 2009 - 2013 terjadi di setiap kelurahan (Affan, 2014).

Peningkatan jumlah penduduk dapat mengakibatkan terjadinya perubahan kualitas lingkungan. Penilaian terhadap kualitas lingkungan bila dikaitkan dengan lokasi penelitian yang terletak di sentra industri kecil memiliki beberapa indikator yaitu ketersediaan air bersih, kualitas udara dan tingkat kebisingan (Maryati, Nisaa, \& Humaira, 2015).

Baiknya kualitas lingkungan permukiman pada sebuah kawasan, mampu memingkatkan kesejahteraan dan kesenangan bagi masyarakat yang tinggal didalamnya (Emmanuel, 2012). Adanya kawasan industri di Kecamatan Genuk secara tidak langsung dapat memberikan pengaruh terhadap struktur permukiman yang ada. Pencemaran lingkungan yang cukup tinggi terjadi di kawasan industri Jawa tengah, Kecamatan Genuk merupakan kecamatan dengan jumlah industri terbanyak di Kota Semarang (Purwanto, 2011).

Permasalahan permukiman di Kecamatan Genuk terkait dengan keberadaan kawasan industri dan bencana rob. Terjadi land subsidence di Kecamatan Genuk dan Sayung terutama pada bagian utara (Rimba et al., 2018). Penduduk masih banyak yang bermukim di Kecamatan Genuk walaupun bagian utara wilayah ini sering terkena banjir rob dan mengalami penurunan muka tanah. Kondisi tersebut dapat berimplikasi pada penurunan kualitas lingkungan permukiman di Kecamatan Genuk.

Penelitian kualitas lingkungan permukiman di Kecamatan Genuk bertujuan untuk menganalisis perubahan kualitas lingkungan permukiman di kawasan industri yang sering terkena bencana banjir rob. 
Lokasi penelitian merupakan Kecamatan Genuk Kota Semarang yang memiliki 13 kelurahan dengan luas wilayah sebesar $27,39 \mathrm{~km} 2$.

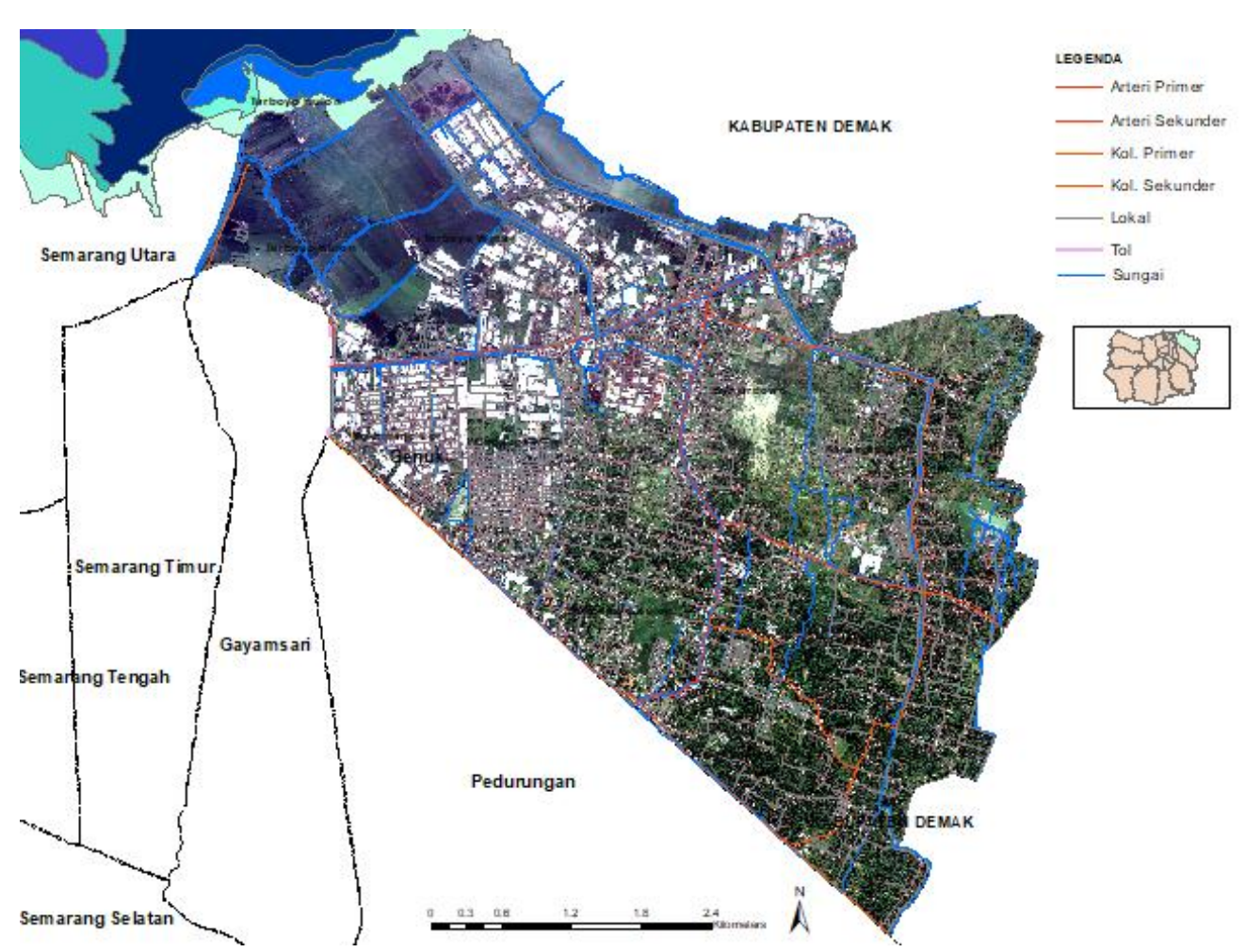

Gambar 1. Peta Citra Kecamatan Genuk

\section{METODE}

Penelitian kualitas lingkungan permukiman di Kecamatan Genuk bertujuan untuk menganalisis perubahan kualitas lingkungan permukiman, menggunakan pendekatan spasial metode penginderaan jauh dan Geographic Information System (GIS). Citra yang digunakan adalah Citra Quickbird Kecamatan Genuk tahun 2006 dan 2016. Teknik analisis menggunakan weighted overlay berdasarkan variabel kepadatan permukiman, tata letak bangunan, kondisi jalan masuk, lebar jalan masuk, pohon pelindung, lokasi permukiman dan kualitas atap bangunan yang mengacu pada Departemen Pekerjaan Umum. Analisis penelitian meliputi :

1) Analisis Kualitas lingkungan permukiman Tahun 2006, bertujuan untuk menganalisis kualitas lingkungan permukiman Kecamatan Genuk pada tahun 2006.

2) Analisis Kualitas lingkungan permukiman Tahun 2016, bertujuan untuk menganalisis kualitas lingkungan permukiman Kecamatan Genuk pada tahun 2016.

3) Analisis perubahan Kualitas lingkungan permukiman Tahun 2006-2016, bertujuan untuk menganalisis perubahan kualitas lingkungan permukiman Kecamatan Genuk pada tahun 2006-2016. ini:

Skoring dan bobot pada masing-masing variabel dapat dilihat dalam Tabel 1 berikut 
Tabel 1. Klasifikasi dan Harkat Parameter Kualitas Lingkungan Permukiman

\begin{tabular}{|c|c|c|c|c|c|}
\hline No & Variabel & Kriteria & Bobot & Skor & Klasifikasi \\
\hline \multirow[t]{3}{*}{1} & kepadatan permukiman & Kepadatan $>60 \%$ & 3 & 3 & Baik \\
\hline & & Kepadatan $40-60 \%$ & & 2 & Sedang \\
\hline & & Kepadatan $<40 \%$ & & 1 & Buruk \\
\hline \multirow[t]{3}{*}{2} & tata letak bangunan & $>50 \%$ bangunan permukiman teratur & 1 & 3 & Baik \\
\hline & & $25-50 \%$ bangunan permukiman teratur & & 2 & Sedang \\
\hline & & $<25 \%$ bangunan permukiman teratur & & 1 & Buruk \\
\hline \multirow[t]{3}{*}{3} & lebar jalan masuk & Lebar jalan masuk $>6 \mathrm{~m}$ & 3 & 3 & Baik \\
\hline & & Lebar jalan masuk 4-6m & & 2 & Sedang \\
\hline & & Lebar jalan masuk $<4 \mathrm{~m}$ & & 1 & Buruk \\
\hline \multirow[t]{3}{*}{4} & kondisi permukaan jalan & $>50 \%$ jalan masuk diperkeras & 2 & 3 & Baik \\
\hline & masuk & $25-50 \% \%$ jalan masuk diperkeras & & 2 & Sedang \\
\hline & & $<25 \%$ jalan masuk diperkeras & & 1 & Buruk \\
\hline \multirow[t]{3}{*}{5} & pohon pelindung jalan & $\begin{array}{l}>50 \% \text { jalan masuk ada pohon } \\
\text { pelindung }\end{array}$ & 2 & 3 & Baik \\
\hline & & $\begin{array}{l}25-50 \% \text { jalan masuk ada pohon } \\
\text { pelindung }\end{array}$ & & 2 & Sedang \\
\hline & & $\begin{array}{l}<25 \% \text { jalan masuk ada pohon } \\
\text { pelindung }\end{array}$ & & 1 & Buruk \\
\hline \multirow[t]{3}{*}{6} & lokasi permukiman & Jauh dari sumber polusi & 2 & 3 & Baik \\
\hline & & Tidak terpengaruh secara langsung & & 2 & Sedang \\
\hline & & Dekat dengan sumber polusi & & 1 & Buruk \\
\hline \multirow[t]{3}{*}{7} & kualitas atap bangunan & $\begin{array}{l}\text { Atap permanen (cor, genteng } \\
\text { beton/tanah) }\end{array}$ & 3 & 3 & Baik \\
\hline & & Atap semi permanen (asbes, seng) & & 2 & Sedang \\
\hline & & Atap non permanen (ilalang) & & 1 & Buruk \\
\hline
\end{tabular}

Sumber : Ditjen Cipta Karya, Departemen Pekerjaan Umum, 2014

Bentuk perhitungan skor total dapat dilihat pada rumus dibawah ini :

Skor total $=($ padat $\times 3)+($ letak $\times 1)+($ kondisi jalan $\times 2)+($ lebar jalan $\times 3)+($ pohon $\times 2)$ $+($ lokasi $\times 2)+($ kualitas atap $\times 3)$

Hasil dari perhitungan tersebut diperoleh jumlah skor tertinggi dan terendah sehingga dapat diketahui selisihnya (range). Berdasarkan pendekatan ini maka klasifikasi kualitas permukiman di peroleh dengan formula:

$\mathrm{Ci}=\mathrm{R}: \mathrm{K}$, dimana:

$\mathrm{Ci}=$ interval kelas

$\mathrm{R}=$ range ( nilai ini diperoleh dari selisih skor total tertinggi - skor total terendah)

$\mathrm{K}=$ jumlah kelas

Penentuan klas kualitas permukiman dilakukan dengan menghitung:

1. Nilai tertinggi dari skor total yaitu $3 \times 16=48$

2. Nilai terendah dari skor total yaitu $1 \times 16=16$

3. Banyaknya klas yang ditentukan adalah 3 klas, perolehan interval klas yaitu (48 - 16) / 3 $=10.666=11$

dimana, angka 16 diperoleh dari penjumlahan nilai faktor penimbang. Pengklasan harkat untuk klas kualitas permukiman disajikan dalam Tabel 2 berikut:

Tabel 2. Klasifikasi Kualitas Lingkungan Permukiman

\begin{tabular}{llc}
\hline Total harkat & Kriteria & Klas \\
\hline $38-48$ & Kualitas baik & I \\
$27-37$ & Kualitas Sedang & II \\
$16-26$ & Kualitas Buruk & III \\
\hline \multicolumn{2}{c}{ Sumber : Analisis, 2018}
\end{tabular}

Sumber : Analisis, 2018 


\section{HASIL DAN PEMBAHASAN}

1) Kualitas lingkungan permukiman Tahun 2006

Analisis Kualitas lingkungan permukiman Tahun 2006 dilakukan dengan teknik overlay pada 7 variabel sebagai berikut:

a. Kepadatan Permukiman

Kepadatan permukiman di Kecamatan Genuk tahun 2006 didominasi oleh permukiman dengan kepadatan tinggi (kondisi buruk) pada enam kelurahan, yaitu Kelurahan Muktiharjo Lor, Kelurahan Gebangsari, Kelurahan Genuksari, Kelurahan Bangetayu Wetan, Kelurahan Trimulyo, dan Kelurahan Terboyo Wetan. Sedangkan, kepadatan permukiman rendah (kondisi baik) hanya terdapat pada dua kelurahan, yaitu Kelurahan Bangetayu Kulon dan Kelurahan Sembungharjo. Kondisi ini sesuai dengan hasil penelitian yang telah dilakukan oleh Agus Anggoro Sigit (2011).

b. Tata Letak Bangunan

Hasil analisis tata letak bangunan di Kecamatan Genuk pada tahun 2006 ialah kecamatan ini didominasi oleh tata letak bangunan dengan klasifikasi sedang yang terdapat pada tujuh kelurahan, yaitu Kelurahan Genuksari, Kelurahan Bangetayu Wetan, Sembungharjo, Penggaron Lor, Karangroto, Banjardowo, dan Trimulyo. Satusatunya kelurahan dengan klasifikasi buruk ialah Kelurahan Terboyo Wetan. Kondisi ini sesuai dengan hasil penelitian sebelumnya oleh Ekartaji, Yunus \& Rahardjo (2014).

c. Lebar Jalan Masuk Permukiman

Kecamatan Genuk didominasi oleh klasifikasi baik dengan jumlah lima kelurahan pada tahun 2006. Kelima kelurahan tersebut ialah Kelurahan Muktiharjo Lor, Gebangsari, Genuksari, Bangetayu Kulon, dan Sembungharjo. Sedangkan, terdapat 4 kelurahan yang termasuk dalam klasifikasi sedang, yaitu Kelurahan Penggaron Lor, Kudu, Karangroto dan Banjardowo. Dua kelurahan lainnya termasuk dalam klasifikasi buruk, yaitu Kelurahan Bangetayu Wetan, dan Terboyo Wetan. Hasil ini cukup relevan dengan penelitian sebelumnya oleh Dyah Respati Suryo Sumunar (2002).

d. Kondisi Jalan Masuk Permukiman

Kecamatan Genuk memiliki kondisi jalan masuk permukimand engan klasifikasi baik pada empat kelurahan, yaitu Kelurahan Muktiharjo Lor, Gebangsari, Genuksari dan Bangetayu Kulon. Sedangkan kelurahan dengan klasifikasi buruk juga terdapat pada empat kelurahan, yaitu Kelurahan Kudu, Penggaron Lor, Terboyo Wetan, dan Trimulyo. Empat kelurahan lainnya termasuk dalam kategori sedang.

e. Pohon Pelindung

Pada tahun 2006 Kecamatan Genuk terdapat satu kelurahan dengan klasifikasi sedang, dua kelurahan dengan klasifikasi buruk, sedangkan lainnya termasuk klasifikasi baik. Sedangkan, Kelurahan Trimulyo dan Kelurahan Terboyo Wetan termasuk ke dalam klasifikasi buruk.

f. Lokasi Permukiman

Kecamatan Genuk didominasi oleh klasifikasi buruk pada tahun 2006. Terdapat 9 kelurahan dengan klasifikasi buruk, yaitu Kelurahan Muktiharjo Lor, Gebangsari, Genuksari, Bangetayu Kulon, Penggaron Lor, Banjardowo, Trimulyo, dan Terboyo Wetan. Sedangkan, terdapat 3 kelurahan dengan klasifikasi sedang yaitu Kelurahan Bangetayu Wetan, Sembungharjo dan Kudu.

\section{g. Kualitas Atap Bangunan}

Kualitas atap bangunan di Kecamatan Genuk pada tahun 2006 pada semua kelurahan termasuk dalam klasifikasi baik. 
Berikut adalah hasil analisis kualitas lingkungan permukiman Kecamatan Genuk tahun 2006 :

Tabel 2. Kualitas Lingkungan Permukiman menurut kelurahan Kecamatan Genuk tahun 2006

\begin{tabular}{|c|c|c|c|c|c|c|c|c|c|c|}
\hline \multirow[t]{2}{*}{ No } & \multirow[t]{2}{*}{ Kelurahan } & \multicolumn{7}{|c|}{ Skor } & \multirow{2}{*}{$\begin{array}{l}\text { Total } \\
\text { Skor }\end{array}$} & \multirow[t]{2}{*}{ Kelas } \\
\hline & & $\begin{array}{l}\mathrm{KP} \\
(3)\end{array}$ & $\begin{array}{l}\text { TLB } \\
\text { (1) }\end{array}$ & $\begin{array}{l}\text { LJM } \\
\text { (3) }\end{array}$ & $\begin{array}{l}\text { KJM } \\
(2)\end{array}$ & $\begin{array}{l}\text { PP } \\
\text { (2) }\end{array}$ & $\begin{array}{l}\text { LP } \\
(2)\end{array}$ & $\begin{array}{l}\text { KAB } \\
(3)\end{array}$ & & \\
\hline 1 & Muktiharjo Lor & 1 & 3 & 3 & 3 & 3 & 1 & 3 & 38 & I \\
\hline 2 & Gebangsari & 1 & 3 & 3 & 3 & 3 & 1 & 3 & 38 & I \\
\hline 3 & Genuksari & 1 & 2 & 3 & 3 & 3 & 1 & 3 & 37 & ॥ \\
\hline 4 & Bangetayu Kulon & 3 & 3 & 3 & 3 & 3 & 1 & 3 & 44 & 1 \\
\hline 5 & $\begin{array}{l}\text { Bangetayu } \\
\text { Wetan }\end{array}$ & 1 & 1 & 1 & 2 & 3 & 2 & 3 & 30 & ॥ \\
\hline 6 & Sembungharjo & 3 & 2 & 3 & 2 & 3 & 2 & 3 & 43 & I \\
\hline 7 & Penggaron Lor & 2 & 2 & 2 & 1 & 3 & 1 & 3 & 33 & ॥ \\
\hline 8 & Kudu & 2 & 2 & 2 & 1 & 3 & 2 & 3 & 35 & ॥ \\
\hline 9 & Karangroto & 2 & 2 & 2 & 2 & 3 & 1 & 3 & 35 & II \\
\hline 10 & Banjardowo & 2 & 2 & 2 & 2 & 2 & 1 & 3 & 33 & II \\
\hline 11 & Trimulyo & 1 & 2 & 1 & 1 & 1 & 1 & 3 & 23 & III \\
\hline 12 & Terboyo Wetan & 1 & 1 & 1 & 1 & 1 & 1 & 3 & 22 & III \\
\hline 13 & Terboyo Kulon & & & & & & & & 0 & \\
\hline
\end{tabular}

Sumber: Analisis Penulis, 2018

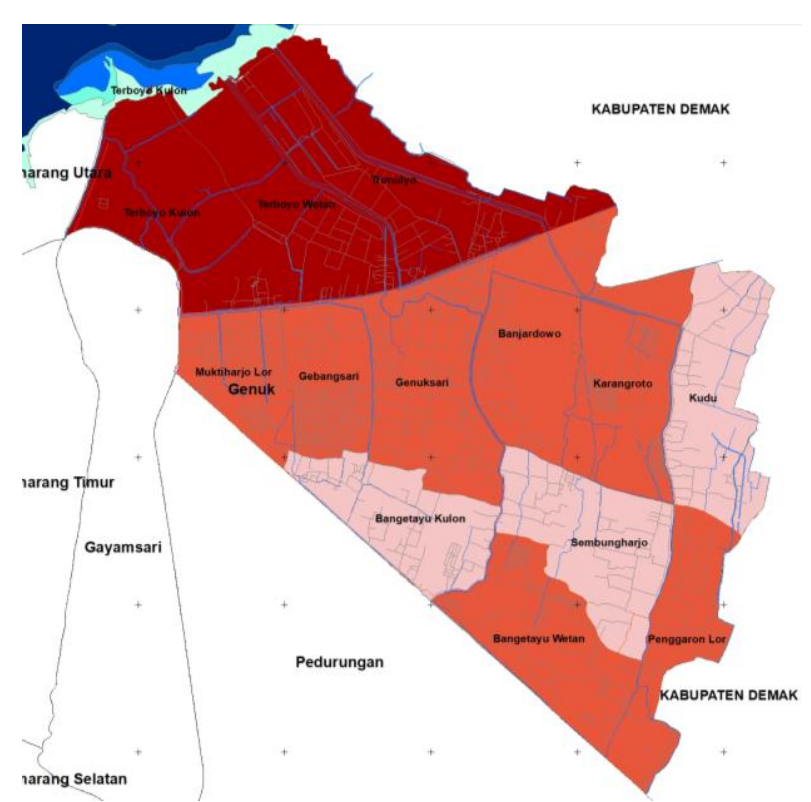

Gambar 2. Peta Kualitas Lingkungan Permukiman Kecamatan Genuk Tahun 2006

Hasil analisis kualitas lingkungan permukiman tahun 2006 di Kecamatan Genuk yaitu terdapat 4 kelurahan dengan kelas baik, 6 kelurahan dengan kelas sedang, dan 2 kelurahan dengan klasifikasi buruk (Tabel 2.). Kelurahan dengan klasifikasi baik dan memiliki skor paling tinggi yaitu Kelurahan Bangetayu Kulon. Kelurahan tersebut termasuk ke dalam 
kelas baik karena didominasi oleh tata letak bangunan yang teratur, kepadatan permukiman masih jarang, lebar jalan masuk cukup lebar, pohon pelindung di kanan kiri jalan masuk permukiman terdapat banyak, serta kualitas atap bangunan yang baik. Kualitas baik pada 3 kelurahan lainnya memiliki total skor yang berbeda dikarenakan skor masingmasing variabel penyusunnya pun berbeda-beda tergantung pada kondisi masing-masing kelurahan. Sedangkan, Kelurahan Genuksari merupakan kelurahan dengan kualitas lingkungan permukiman sedang yang memiliki skor kelas II paling tinggi. Kelurahan Genuksari terdiri dari lebar jalan masuk permukiman, kondisi jalan masuk permukiman, pohon pelindung, serta kualitas atap bangunan dengan klasifikasi baik. Kemudian, kelas buruk dengan skor terendah terdapat pada Kelurahan Terboyo Wetan yang hanya memiliki kualitas atap bangunan permanen namun pada variabel lainnya kelurahan ini termasuk dalam kategori buruk. Kondisi kelurahan yang memiliki banyak permukiman dengan kepadatan tinggi dan memiliki lebar jalan masuk yang sempit menjadi salah satu factor permukiman di kelurahan tersebut menjadi buruk. Hasil ini sesuai dengan penelitian sebelumnya yang dilakukan oleh Tyastiti Nugraheni, Agus Dwi Martono, dan Aditya Saputra (2013). Distribusi spasial kualitas lingkungan permukiman Kecamatan Genuk tahun 2006 dapat dilihat pada gambar berikut:

2) Kualitas lingkungan permukiman tahun 2016

a. Kepadatan Permukiman

Kepadatan permukiman di Kecamatan Genuk pada tahun 2016 yaitu terdapat dua kriteria kepadatan permukiman. Kedua kriteria kepadatan permukiman tersebut ialah kepadatan permukiman $40-60 \%$ dan kepadatan permukiman $>60 \%$. Kriteria $40-60 \%$ hanya terdapat pada 4 kelurahan, yaitu Kelurahan Bangetayu Wetan, Kelurahan Penggaron Lor, Kelurahan Kudu, dan juga Kelurahan Karangroto. Sedangkan sembilan kelurahan lainnya termasuk ke dalam kriteria kepadatan permukiman $>60 \%$ buruk.

b. Tata Letak Bangunan

Pada tahun 2016, hasil analisis tata letak bangunan di Kecamatan Genuk ialah didominasi oleh klasifikasi sedang yang terdapat pada tujuh kelurahan, yaitu Kelurahan Bangetayu Kulon, Sembungharjo, Penggaron Lor, Kudu, Karangroto, Banjardowo, dan Trimulyo. Terdapat 3 kelurahan dnegan klasifikasi baik yaitu di Kelurahan Muktiharjo Lor, Gebangsari, dan Bangetayu Kulon. Sedangkan 3 kelurahan lainnya yaitu kelurahan Bangetayu Wetan, Terboyo Wetan dan Terboyo Kulon termasukdalam klasifikasi buruk.

c. Lebar Jalan Masuk Permukiman

Hasil analisis lebar jalan masuk tahun 2016, Kecamatan Genuk didominasi oleh klasifikasi buruk yang terdapat pada enam kelurahan yaitu Kelurahan Sembungharjo, Bangetayu Kulon, Banjardowo, Trimulyo, Terboyo Wetan dan Terboyo Kulon. Sedangkan, pada klasifikasi baik terdapat 3 kelurahan yaitu Kelurahan Muktiharjo Lor, Gebngsari, dan Genuksari.

d. Kondisi Jalan Masuk Permukiman

Hasil analisis kondisi permukaan jalan masuk permukiman Kecamatan Genuk pada tahun 2016 menunjukkan bahwa terdapat enam kelurahan dengan klasifikasi baik yaitu Kelurahan Muktiharjo Lor, Gebangsari, Genuksari, Bangetayu Kulon, Karangroto, dan Banjardowo. Selain itu, terdapat empat kelurahan dengan klasifikasi buruk yaitu Kelurahan Bangetayu Wetan, Sembungharo, Penggaron Lor, dan Kudu. Sedangkan, 3 kelurahan liannya termasuk dalam klasifikasi sedang. Hasil tersebut sesuai dengan penelitian sebelumnya oleh Wahyu Tirto Prasetyo dan Sri Rahayu (2013).

e. Pohon Pelindung 
Pada tahun 2016, Kecamatan Genuk didominasi oleh klasifikasi pohon pelindung baik pada 6 kelurahan, yaitu Kelurahan Bangetayu Wetan, Sembungharjo, Penggaron Lor, Kudu,Banjardowo dan Karangroto. Sedangkan klasifikasi buruk terdapat pada 2 kelurahan yaitu Kelurahan Terboyo Wetan dan Terboyo Kulon. Kondisi ini sesuai dengan hasil penelitian sebelunhya oleh Aris Kurniadi (2014).

f. Lokasi Permukiman

Kecamatan Genuk hanya memiliki 1 kelurahan yang termasuk dalam kategori sedang, yaitu Kelurahan Bangetayu Wetan. 12 kelurahan lainnya termasuk dalam kategrori buruk, yaitu Kelurahan Muktiharjo Lor, Gebangsari, Genuksari, Bangetayu Kulon, Sembungharjo, Penggaron Lor, Kudu, Karangroto, Banjardowo, Trimulyo, Terboyo Wetan dan Terboyo Kulon. Hasil analisis ini sesuai dengan penelitian sebelumnya oleh Gesit Yoga Ambarasakti (2013).

g. Kualitas Atap Bangunan

Kualitas atap bangunan di Kecamatan Genuk pada tahun 2016 sudah menggunakan atap permanen, baik yang menggunakan asbes maupun genteng sehingga semua kelurahan termasuk dalam klasifikasi baik.

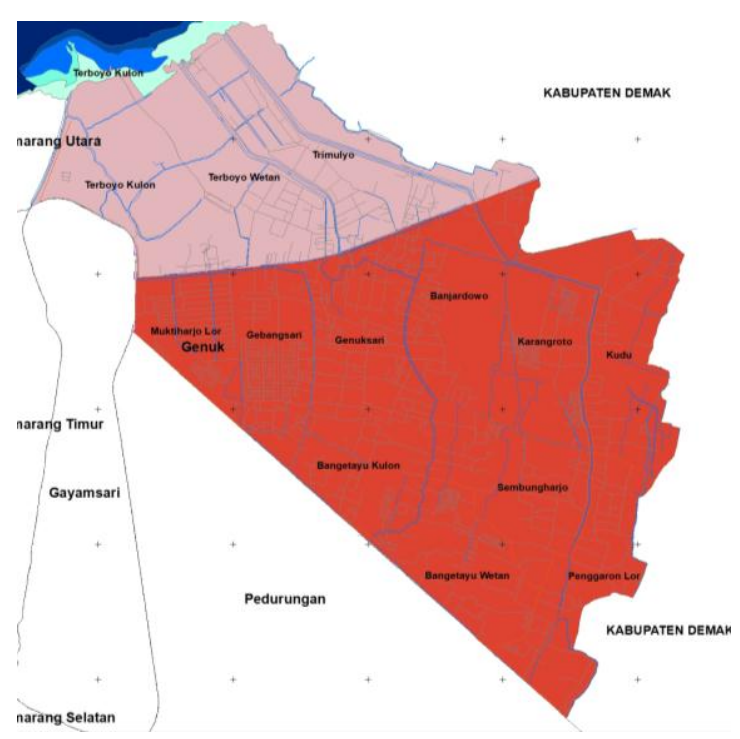

Gambar 3. Peta Kualitas Lingkungan Permukiman Kecamatan Genuk Tahun 2016

Hasil analisis kualitas lingkungan permukiman tahun 2016 di Kecamatan Genuk terdapat dua kelas, yaitu kelas II dan kelas III . Pada tahun 2016, terdapat 3 kelas III (kelas buruk), yaitu Kelurahan Trimulyo, Kelurahan Terboyo Wetan, dan Kelurahan Terboyo Kulon. Kelurahan Terboyo Kulon merupakan kelurahan dengan kualitas lingkungan permukiman buruk dan memiliki skor paling rendah. Kelurahan tersebut tidak memiliki permukiman yang luas namun sebagian besar permukimannya ialah permukiman dengan kepadatan tinggi yang berada di bantaran sungai dan hanya terdapat akses jalan yang sempit. Sedangkan, Kelurahan Karangroto merupakan kelurahan dengan total skor paling tinggi untuk kualitas lingkungan permukiman pada tahun 2016. Permukiman di kelurahan ini didominasi dengan kondisi permukaan jalan masuk yang sudah diperkeras. Selain itu, masih banyak terdapat pohon pelindung pada sebelah kanan kiri jalan masuk permukiman. 
Kondisi tersebut membuat Kelurahan Karangroto termasuk dalam kelas sedang pada tahun 2016.

3) Perubahan kualitas lingkungan permukiman

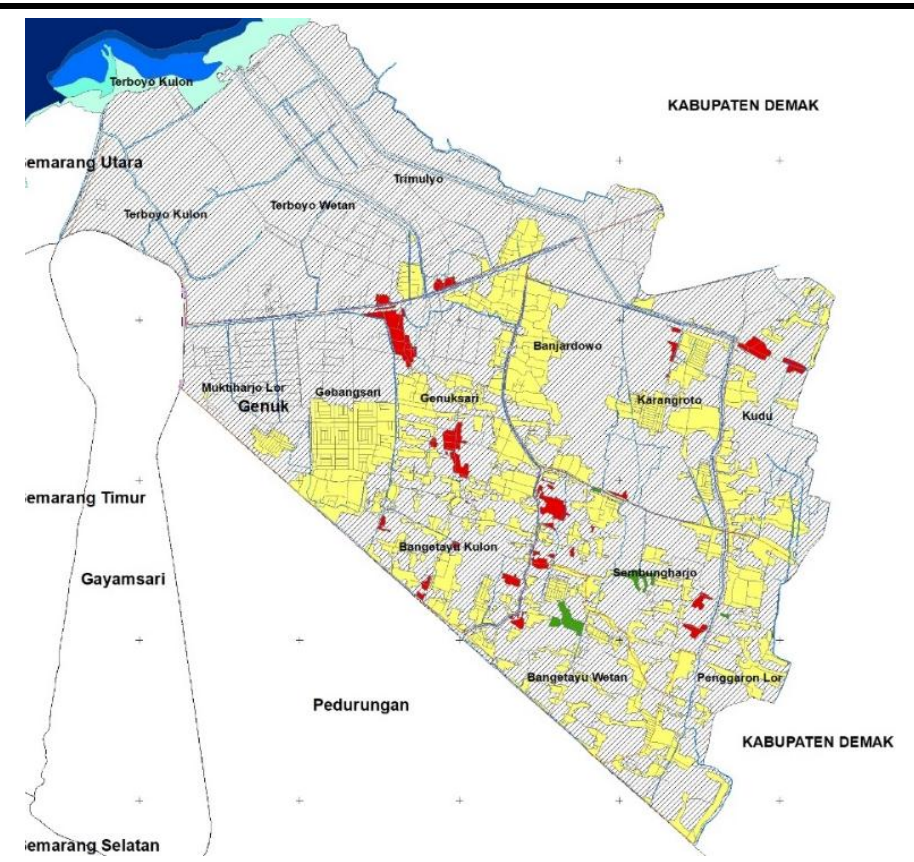

Gambar 4. Peta Perubahan Kualitas Lingkungan Permukiman Kecamatan Genuk Tahun 2006-2016

Perubahan kualitas lingkungan permukiman yang terjadi di Kecamatan Genuk dari 2006 sampai 2016 cukup banyak. Terdapat 4 kelurahan yang berubah yaitu Kelurahan Muktiharjo Lor, Gebangsari, Bangetayu Kulon, dan Sembungharjo. Keempat kelurahan tersebut berubah semakin buruk dalam waktu 10 tahun yaitu dari kelas I atau kelas baik menjadi kelas II atau kelas sedang. Gambar 4.22 berikut merupakan distribusi spasial perubahan tingkat kualitas lingkungan permukiman di Kecamatan Genuk.

Perubahan yang sangat mencolok terdapat di Kelurahan Bangetayu Kulon. Kelurahan Bangetayu Kulon mengalami perubahan kepadatan permukiman dari rendah ke tinggi. Selain itu, perubahan pada ketersediaan pohon pelindung pada jalan masuk permukiman yang makin sedikit juga merupakan salah satu factor kualitas lingkungan permukiman kelurahan tersebut berubah. Hal tersebut dapat disebabkan masih tersedianya lahan kosong untuk digunakan sebagai permukiman di Kelurahan Bangetayu Kulon. Kelurahan tersebut juga memiliki factor penarik berupa dekatnya akses terhadap tempat kerja dan harga lahan yang belum begitu tinggi, sehingga wajar apabila menjadi salah satu alternative pilihan untuk tempat tinggal. 
Tabel 2. Perubahan Klasifikasi Kualitas Lingkungan Permukiman Kecamatan Genuk

\begin{tabular}{lllllll}
\hline No & Kelurahan & Skor & \multicolumn{3}{c}{ Kelas } & Perubahan \\
\cline { 3 - 5 } & & 2006 & $\mathbf{2 0 1 6}$ & 2006 & 2016 & \\
\hline 1 & Muktiharjo Lor & 38 & 34 & I & II & Semakin buruk \\
2 & Gebangsari & 38 & 36 & I & II & Semakin buruk \\
3 & Genuksari & 37 & 35 & II & II & Tetap \\
4 & Bangetayu Kulon & 44 & 30 & I & II & Semakin buruk \\
5 & Bangetayu Wetan & 30 & 35 & II & II & Tetap \\
6 & Sembungharjo & 43 & 28 & I & II & Semakin buruk \\
7 & Penggaron Lor & 33 & 33 & II & II & Tetap \\
8 & Kudu & 35 & 33 & II & II & Tetap \\
9 & Karangroto & 35 & 37 & II & II & Tetap \\
10 & Banjardowo & 33 & 31 & II & II & Tetap \\
11 & Trimulyo & 23 & 25 & III & III & Tetap \\
12 & Terboyo Wetan & 22 & 25 & III & III & Tetap \\
13 & Terboyo Kulon & & 22 & & III & \\
\hline
\end{tabular}

Sumber : Hasil analisis, 2018

Keterangan:
Tetap, apabila kelas/bobot tetap pada tahun 2006 dan 2016
Semakin buruk, apabila kelas/bobot mengalami penurunan dari tahun 2006 ke 2016
Semakin baik, apabila kelas/bobot mengalami peningkatan dari tahun 2006 ke 2016

Luas lahan permukiman di kawasan pinggiran Kota Semarang mengalami peningkatan. Kondisi ini dimungkinkan karena masih tersedia lahan yang dapat dimanfaatkan untuk lahan permukiman (non terbangun) (Septi \& Bitta, 2015). Keterbatasan lahan di Kecamatan Genuk mendesak pertumbuhan permukiman ke arah selatan. Hal tersebut berkaitan dengan tingginya kejadian rob yang terjadi di bagian utara dan juga banyaknya industry aktif di kelurahan-kelurahan utara wilayah ini. Ketersediaan lahan kosong yang masih banyak di Kecamatan Genuk bagian selatan pun dapat menjadi salah satu faktor penarik lainnya, dikarenakan harga lahan di wilayah Genuk tidak terlalu mahal seperti kecamatan lainnya di Kota Semarang. Kelurahan Gebangsari yang pada tahun 2006 termasuk ke dalam kualitas baik menjadi kelurahan dengan kualitas sedang pada tahun 2016. Hal ini dapat disebabkan adanya penambahan bangunan permukiman namun tidak tertata dengan baik, begitu juga dengan pohon pelindung jalan masuk permukiman yang makin berkurang. Hal lainnya yang dapat berpengaruh terhadap penurunan kualitas lingkungan ialah lebar jalan masuk permukiman yang baru tumbuh setelah tahun 2006 lebarnya $<4 \mathrm{~m}$ sehingga masuk ke dalam kelas buruk. Semakin padatnya permukiman di Kelurahan Sembungharjo juga menjadi salah satu penyebab penurunan kualitas lingkungan berkaitan dengan pertumbuhan permukiman tersebut bisa dekat dengan industri, jalan lebar masuk permukiman sempit, tidak terdapat pohon pelindung yang memadai hingga kondisi jalan masuk permukiman yang belum semuanya diperkeras.

Kondisi sosial ekonomi yang dimiliki Kecamatan Genuk berbeda dengan kondisi social ekonomi Kecamatan Mijen meskipun sama-sama berada di kawasan pinggiran Kota Semarang. Hal ini dikarenakan karakteristik Kecamatan Mijen sebagai lahan pertanian sedangkan Kecamatan Genuk sebagai kawasan industry, sehingga terjadi perbedaan pada pendapatan masyarakat kedua kecamatan tersebut. Pendapatan masyarakat Kecamatan Mijen rata-rata Rp 1.500.000,00 per bulan (Pigawati, 2011). Sedangkan, di Kecamatan Genuk rata-rata Rp 1.700.000,00 per bulan.

Perubahan kualitas lingkungan permukiman yang cukup mencolok di Kecamatan Genuk dalam waktu 10 tahun hanya terjadi pada 4 kelurahan. Sedangkan kelurahan lainnya walaupun kelasnya tetap sama namun memiliki skor yang berbeda pada tahun 2006 dan tahun 2016. Sebagian besar dari kelurahan tersebut mengalami peningkatan skor, yaitu Kelurahan Karangroto, Kelurahan Bangetayu Wetan, Kelurahan Trimulyo, dan Kelurahan 
Terboyo Wetan. Hal ini dapat diartikan bahwa terdapat kualitas lingkungan yang membaik di Kecamatan Genuk. Hasil perubahan kualitas lingkungan permukiman ini sesuai dengan penelitian sebelumnya oleh Gesit Yoga Ambarasakti (2013).

\section{KESIMPULAN}

Berdasarkan penelitian yang telah dilakukan, terdapat 3 kelas kualitas lingkungan permukiman pada tahun 2006 yaitu kelas I (baik), kelas II (sedang), kelas III (buruk). Sedangkan, pada tahun 2016 hanya terdapat 2 kelas kualitas lingkungan permukiman, yaitu kelas II (sedang), kelas III (buruk). Permukiman yang berada pada kelas III, didominasi oleh bangunan yang cenderung rapat dan tidak memiliki halaman luas. Penduduk yang ada didalamnya pun kebanyakan berpenghasilan menengah ke bawah. Degradasi lingkungan dapat disebabkan oleh kemiskinan (Duraiappah, 1996). Hal ini dapat dilihat dengan banyaknya permukiman kelas III yang berada di utara Kecamatan Genuk. Jika peningkatan tingkat pendapatan dapat diwujudkan, diharapkan dapat meningkatkan kualitas hidup melalui pemenuhan layak perumahan dan akses untuk pelayanan publik dapat diberikan secara mandiri oleh masyarakat (Yuliastuti \& Saraswati, 2014). Sangat penting untuk memiliki kebijakan yang lebih inovatif terhadap permukiman informal perkotaan sebagai alat untuk mengatur fungsi lahan dan memastikan pelestarian lingkungan di pinggiran kota (Aguilar \& Santos, 2011).

Perubahan kualitas lingkungan permukiman di Kecamatan Genuk ini menunjukkan bahwa, dalam kurun waktu 10 tahun, terdapat banyak factor yang dapat mempengaruhi berubahnya kualitas lingkungan permukiman suatu kawasan. Dalam penelitian ini, perubahan kualitas lingkungan permukiman di Kecamatan Genuk dipengaruhi oleh berubahnya fungsi lahan, kepadatan bangunan, keberadaan pohon pelindung, serta kondisi perkerasan jalan masuk permukiman.

\section{UCAPAN TERIMA KASIH}

Penulis mengucapkan terima kasih kepada pengelola Kecamatan Genuk, BPS Kota Semarang, Bappeda Kota Semarang, dan Departemen Perencanaan Wilayah dan Kota sebagai institusi yang telah memfasilitasi sehingga penelitian ini dapat diselesaikan dengan baik. Terimakasih juga penulis sampaikan kepada seluruh pemilik artikel yang digunakan sebagai sitasi artikel ini.

\section{DAFTAR PUSTAKA}

Affan, F. M. (2014). Analisis Perubahan Penggunaan Lahan Untuk Permukiman Dan Industri Dengan Menggunakan Sistem Informasi Geografis (SIG), 2(1), 49-60.

Aguilar, A. G. (2008). Peri-urbanization, illegal settlements and environmental impact in Mexico City, 25, 133145. https://doi.org/10.1016/j.cities.2008.02.003

Aguilar, A. G., \& Santos, C. (2011). Land Use Policy Informal settlements' needs and environmental conservation in Mexico City : An unsolved challenge for land-use policy §. Land Use Policy, 28(4), 649662. https://doi.org/10.1016/j.landusepol.2010.11.002

Ambarasakti, Gesit Yoga. (2013). Analisis Kualitas Lingkungan Permukiman Dengan Menggunakan Aplikasi Citra Penginderaan Jauh Tahun 2006 Dan 2010 Di Kecamatan Sewon Kabupaten Bantul. Universitas Muhammadiyah Surakarta Fakultas Geografi Surakarta.

Anggoro, Agus Sigit. 2011. Analisis Kondisi Kualitas Lingkungan Permukiman Menggunakan Citra Quickbird Di Kecamatan Depok Kabupaten Sleman. Fakultas Geografi UMS Surakarta.

Doxiadis, C. A. (1968). Ekistic, An Introduction to the Science of Human Settlements. London: Hutchinson and Co, Ltd.

Duraiappah, A. (1996). Poverty and Environmental Degradation : a Literature Review and Analysis, (8).

Ekartaji, Prittaningtyas., Yunus, Hadi Sabari., dan Rahardjo, Noorhadi. (2014). Kajian Kualitas Lingkungan Permukiman di Daerah Pinggiran Kota Kasus di Desa Ngestiharjo, Yogyakarta. Fakultas Geografi UGM. 
Emmanuel, J. B. (2012). “Housing Quality” To the Low Income Housing Producers in Ogbere, Ibadan, Nigeria. Procedia - Social and Behavioral Sciences, 35(December 2011), 483-494. https://doi.org/10.1016/j.sbspro.2012.02.114

Kurniadi, Aris. (2014). Analisis Kualitas Lingkungan Permukiman Di Kecamatan Kotagede Kota Yogyakarta Menggunakan Citra Quickbird. Program Studi Pendidikan Geografi Fakultas Ilmu Sosial Universitas Negeri Yogyakarta.

Kusrini, Suharyadi, dan Hardoyo, Su Rito. (2011). Perubahan Penggunaan Lahan Dan Faktor Yang Mempengaruhinya Di Kecamatan Gunungpati Kota Semarang. MGI. Vol. 25, No. 1, Maret 2011 (25 - 40). Fakultas Geografi UGM dan Ikatan Geograf Indonesia .

MacDonald, J., Ziss, R. (n.d.). Living and Working Informally in Urban Areas, in Bundesamt fur Bauwesen und Raumordnung (BBR) (ed). London: E\&FN Spon.

McManus, P and Haughton, G (2006) Planning with ecological footprints: a sympathetic critique of theory and practice. Environment and Urbanization 18(No. 1), 113-127.

Maryati, S., Nisaa, A., \& Humaira, S. (2015). Increasing the Infrastructure Access of Low-Income People in PeriUrban of Bandung Metropolitan Area. International Journal of Built Environment and Sustainability, 2(3), 219-226.

Nugraheni, Tyastiti., Martono, Agus Dwi., dan Saputra, Aditya. (2013). Analisis Kualitas Lingkungan Permukiman Menggunakan Citra Quickbird Di Kecamatan Kotagede Kota Yogyakarta. Fakultas Geografi Universitas Muhammadiyah Surakarta

Pigawati, B. (2011). Use of Satellite Imagery f or Study of Settlement Area i n Semarang City, 25(2), 140-151.

Prasetyo, Wahyu Tirto dan Rahayu, Sri. (2013). Kajian Kualitas Permukiman Dengan Citra Quickbird Dan SIG Di Kecamatan Serengan Kota Surakarta. Jurnal Teknik PWK Volume 2 Nomor 22013.

Purwanto, A. (2011). Pengaruh Tipe Industri, Ukuran Perusahaan, Profitabilitas, Terhadap Corporate Social Responsibility. Jurnal Akuntansi \& Auditing, 8 (1), 1-94.

Rimba, A. B., Osawa, T., Parwata, I. N. S., As-syakur, R., Kasim, F., \& Astarini, I. A. (2018). Physical assessment of coastal vulnerability under enhanced land subsidence in Semarang, Indonesia, using multi-sensor satellite data. Advances in Space Research. https://doi.org/10.1016/j.asr.2018.01.026

Rojas. (1989). Human settlements of the Eastern Caribbean.

Septi, R., \& Bitta, A. (2015). KAJIAN PERKEMBANGAN KECAMATAN MIJEN SEBAGAI DAMPAK PEMBANGUNAN BUKIT SEMARANG BARU ( BSB CITY ) PENDAHULUAN Urbanisasi tidak dapat dipisahkan dari isu utamanya yaitu mengenai tingginya pertumbuhan jumlah penduduk yang berdampak pada keruangan. Dimana den, 4(1).

Sumunar, Dyah Respati Suryo. (2002). Kajian Kualitas Lingkungan Permukiman Kota Yogyakarta Bagian Selatan Dengan Foto Udara Pankromatik Hitam Putih Dan Sistem Informasi Geografis. Fakultas Ilmu Sosial Universitas Negeri Yogyakarta.

Sutanto. (1995). Penginderaan Jauh Dasar Jilid II. Yogyakarta: Gadjah Mada University Press.

Ward P.J., Marfai M.A., Yulianto F., Hizbaron D.R. \& Aerts J.C.J.H. 2011. Coastal inundation and damage exposure estimation: a case study for Jakarta. Natural Hazards, 56, 899-916.

Whyne-Hammond, C. (1985). Elements of Human Geography. London: George \& Unwin.

Yunus Hadi Sabari. 2010. Metodologi Penelitian Wilayah Kontemporer. Yogyakarta : Pustaka Pelajar.

Yuniawan, Rahmad. (2011). Analisis Kondisi Kualitas Lingkungan Permukiman Menggunakan Citra Quickbird Di Kecamatan Depok Kabupaten Sleman. Fakultas Geografi Universitas Muhammadiyah Surakarta

Yuliastuti, N., \& Saraswati, N. (2014). Environmental Quality in Urban Settlement : The Role of Local Community Association in East Semarang Sub-District. Procedia - Social and Behavioral Sciences, 135, 31-35. https://doi.org/10.1016/j.sbspro.2014.07.321 